\title{
Ampulla of Vater Cancer pT1 TNM Finding v7
}

National Cancer Institute

\section{Source}

National Cancer Institute. Ampulla of Vater Cancer pT 1 TNM Finding v7. NCI Thesaurus.

Code C90270.

Ampulla of Vater cancer with tumor limited to ampulla of Vater or sphincter of Oddi.

(from AJCC 7th Ed.) 